\title{
Observational evidence for the impact of the lake breeze circulation on ozone concentrations in Southern Ontario
}

\author{
D.R. Hastie ${ }^{\mathrm{a}, *}$, J. Narayan ${ }^{\mathrm{a}}$, C. Schiller ${ }^{\mathrm{a}}$, H. Niki ${ }^{\mathrm{a}, 1}$, P.B. Shepson ${ }^{\mathrm{a}, \mathrm{b}}$, \\ D.M.L. Sills ${ }^{c}$, P.A. Taylor ${ }^{c}$, Wm.J. Moroz ${ }^{d}$, J.W. Drummond ${ }^{\mathrm{e}}$, \\ N. Reidf, R. Taylor ${ }^{\mathrm{a}, \mathrm{g}}$, P.B. Roussel ${ }^{\mathrm{g}}$, O.T. Melo \\ "Department of Chemistry and Centre for Atmospheric Chemistry, York University, 4700 Keele St., North York, Ontario, Canada M3J IP3 \\ ${ }^{\circ}$ Departments of Chemistry, and Earth and Atmospheric Sciences, Purdue University, West Lafayette IND, USA \\ 'Department of Earth and Atmospheric Science, York University, 4700 Keele St., North York, Ontario, Canada M3J IP3 \\ d Wm. J. Moroz Assaciates, Hastings, Ontario, Canada \\ 'Unisearch Associates, 222 Snidercroft, Concord Ontario, Canada \\ 'Ontario Ministry of the Environment and Energy, St. Clair Avenue, West Toronto, Ontario, Canada \\ s Ontario Hydro Technologies, Kipling Avenue, Toronto, Ontario, Canada
}

\begin{abstract}
Very rapid increases in the concentrations of ozone and ozone precursors, in the late afternoon, have been observed at a rural and an urban site in southern Ontario. Ozone concentration increases of $30 \mathrm{ppbv}$ in a few minutes have been observed. These increases occur simultaneously with the arrival of a Lake Ontario lake breeze front as identified from meteorological measurements and visible satellite imagery. This indicates that polluted air masses from over Lake Ontario are being transported inland by the lake breeze. Aircraft measurements of ozone, $\mathrm{NO}_{x}$, and hydrocarbons show such an air mass moving inland. Chemical measurements at the sites show that the polluted air masses are not of local origin, but are of similar age to those regularly encountered in rural areas.
\end{abstract}

Keywords: Oxidant production; Air quality; PAN; Meteorology; Lake breeze

\section{Introduction}

Elevated ozone concentrations are a major environmental concern in many heavily populated areas often extending well downwind of the population centres themselves into rural or agricultural areas. Canada has

\footnotetext{
${ }^{*}$ Corresponding author.

${ }^{1}$ Deceased.
}

set a maximum acceptable ozone concentration of 82 ppbv, for $1 \mathrm{~h}$, to protect both human and vegetative health. The region of Southern Ontario and Southern Quebec that extends from Windsor to Quebec City, the so-called Windsor Quebec corridor (WQC), exceeds this concentration more often than any other part of the country (CCME 1991). As a result of these observations, and because of concerns about the effects on the large population and the intensive agriculture, extensive studies on the factors controlling ozone concentrations in this area have been undertaken. 
The most recent of these studies is the Southern Ontario Oxidant Study (SONTOS). This is a multi-faceted multi-institutional study aimed at gaining a better understanding of ozone production and transport in the Ontario atmosphere. It combines field measurement and modelling components and involves groups from Universities, Government laboratories and the private sector. There have been two major field studies in the summers of 1992 and 1993, with smaller studies in 1991 and 1994. A summary of conclusions from the 1992 study can be found in Reid et al. (1996) and references therein. Chemical measurements in that field study showed a very rapid increase in ozone concentration $(\approx 20 \mathrm{ppbv}$ in less than 30 min at Hastings) on at least one afternoon (Reid et al., 1996). This increase was attributed to the impact of meteorology associated with Lake Ontario but the lim. ited data set precluded more detailed analysis at that time. More recent studies have shown that this effect is more frequent and more widespread than originally indicated and likely due to the lake breeze circulation.

In this paper we examine evidence, collected over 4 yr of the SONTOS study, for the importance of the Lake Ontario lake breeze in transporting air masses containing elevated ozone concentrations over rural areas in the vicinity of the lake.

\section{Experimental}

\subsection{Sites}

We use data obtained from the intensive SONTOS surface sites at Hastings and York University, supplemented with data from aircraft flights. The Hastings site is roughly $150 \mathrm{~km}$ northeast of Toronto and $36 \mathrm{~km}$ from the shore of Lake Ontario, in a lightly populated farming area. The town of Hastings, population 1000 , is $5 \mathrm{~km}$ to the southwest. The nearest major town is Peterborough, approximately $40 \mathrm{~km}$ to the north west. The site itself is on a hill with an average elevation above the immediately surrounding area of about $30 \mathrm{~m}$, and is about $40 \mathrm{~m}$ above the Trent river, a largely recreational waterway.

The York site is located on the roof of the three storey Petrie Building on the Keele Campus of York University. The site is approximately $17 \mathrm{~km}$ north of Lake Ontario on the northern edge of Metropolitan Toronto. The immediate area is light industrial and suburban housing. The University is surrounded by major roads on all four sides, and is $6 \mathrm{~km}$ north and $2.6 \mathrm{~km}$ east of the major east-west and north-south highways, respectively.

A twin engine Piper Seminole aircraft was used for measurements in the boundary layer during transects between Toronto and Hastings. It was based at Guelph, approximately $70 \mathrm{~km}$ west-southwest of Toronto. It performed flights upwind and downwind of Toronto, under- took plume studies, measured vertical profiles and was used to examine the horizontal variability of pollutants between Guelph and Hastings.

\subsection{Instrumentation and methodologies}

The instrumentation and the methodologies used to generate the ground-level SONTOS data sets have largely been described elsewhere (Hastie et al., 1996; Reid et al., 1996; Roussel et al., 1996). Only a brief listing of the techniques is given here.

Ground-based measurements at the two SONTOS sites were made by the following instrumentation: ozone with Dasibi model 1003-AH and Thermoelectron Model 49 UV absorption analysers; $\mathrm{NO}$ and $\mathrm{NO}_{2}$ using a TECAN model CLD 770-AL ppt NO chemiluminescent analyser equipped with a PLC-760 photolytic

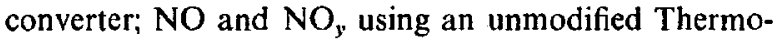
electron model $42 \mathrm{~S}$ high sensitivity chemiluminescent analyser equipped with a molybdenum reduction catalyst; $\mathrm{CO}$ using an unmodified Thermoelectron model 48 non-dispersive infrared gas filter correlation spectrometer; $\mathrm{SO}_{2}$ with a Thermoelectron model $8850 \mathrm{~S}$ highsensitivity fluorescent analyser; PAN using a gas chromatograph with electron capture detection; and hydrogen peroxide and formaldehyde using a tunable diode laser absorption spectrometer. Hydrocarbon samples were collected in $3 /$ summa polished stainless-steel canisters and returned to the laboratory for analysis using GC with FID detection (see Jobson et al., 1994).

The aircraft carried out in situ measurements for temperature, $\mathrm{NO}_{2}, \mathrm{NO}_{x}$, ozone, and collected hydrocarbon samples in stainless-steel canisters. Air was sampled from a point $80 \mathrm{~cm}$ aft of the nose of the aircraft and $15 \mathrm{~cm}$ from the fuselage through individual $6.3 \mathrm{~mm}$ tubes oriented perpendicular to the fuselage. Teflon tubing was used for the analysers and stainless steel for the hydrocarbon sampling. Air temperature was measured by using a thermistor located at the sample inlet, ambient pressure using a Sensym LX1602A and aircraft position by Rockwell International model NavCorV GPS. Altitude was determined by the average of GPS altitude and the onboard pressure-altitude sensor.

Ozone and the $\mathrm{NO}_{x}$ species were measured using Scintrex-Unisearch Luminox ${ }^{\text {B }}$ chemiluminescent analysers. Two LMA-3 $\mathrm{NO}_{2}$ luminol based analysers were flown. The first measured $\mathrm{NO}_{2}$ directly while the second sampled the air via a Permapur Nafion drier and a $\mathrm{CrO}_{3} \mathrm{NO}$ to $\mathrm{NO}_{2}$ converter (Drummond et al., 1989), to measure NO . The LMA-3 data were corrected for ambient pres sure and nonlinearity as described in Drummond et al. (1989). Ozone was measured by a LOZ-3 $\mathrm{O}_{3}$ (Eosin-y) analyser. The LOZ-3 data are corrected for temperature and pressure. The LMA-3s were calibrated and zero checked before, during, and after each flight by an onboard permeation tube calibration system. The LOZ-3 
$\mathrm{O}_{3}$ calibration was checked daily in the laboratory by comparison to a Dasibi model 1003-AH ozone monitor. The instruments were also audited by the Ontario Ministry of the Environment and Energy audit group before and after the flight campaign, and no anomalies were observed.

\section{Observations}

\subsection{Background: The lake and the lake-land circulation}

The difference in heat capacities between land and a large body of water can produce a temperature differential between the land and adjacent water surfaces, especially under clear sky conditions. This results in a corresponding difference in air temperatures which, in the absence of strong gradient flow can generate a localized atmospheric circulation. This phenomenon has been observed for millennia and is usually described as a lake (sea) breeze in the daytime and a land breeze at night (Simpson, 1994). In the daytime the air temperature over the land is higher than over the water and the resulting pressure difference drives a net flow of the cooler air from above the water onto the land (the lake breeze). The air originating over the lake is more dense than the air over land and so is confined to a shallow inflow layer at the surface, typically $500 \mathrm{~m}$ or less in height. The wind speed in this inflow layer is greater than the rate at which this lake breeze circulation can penetrate inland. The resulting convergence, at the leading edge of the denser air, causes the gradients of temperature, moisture and wind to tighten forming a "front". At the front, inflowing air is forced upwards and often produces a narrow band of cumulus clouds that can be identified using visible satellite imagery. This front penetrates inland during the day, until there is no longer a sufficient temperature gradient to maintain it. This typically occurs close to sunset. At night the surface temperature gradient is reversed and the land breeze is produced.

The Great Lakes lake breezes have been found to penetrate inland over large distances. Lyons (1972) found that the lake breeze on the western shore of Lake Michigan could extend up to $40 \mathrm{~km}$ inland. Comer and McKendry (1993) using wind rose maps for 113 summer lake breeze days in 1988 and 1989 , showed that the Lake Ontario lake breeze influence is clearly evident more than $40 \mathrm{~km}$ inland at Peterborough, Ontario and Syracuse, New York. Sills and Moroz (1996) identified at least $6 \mathrm{~d}$ in 1992 and 1993 on which the Lake Ontario lake breeze reached Hastings. Hence, there is ample evidence that the Lake Ontario lake breeze can be expected to reach sites as far from the lake as Hastings, on an occasional basis.

This land-lake (or land-sea) circulation has been implicated as a controlling factor for air quality in areas adjacent to the ocean or a large lake (Lyons and Cole,

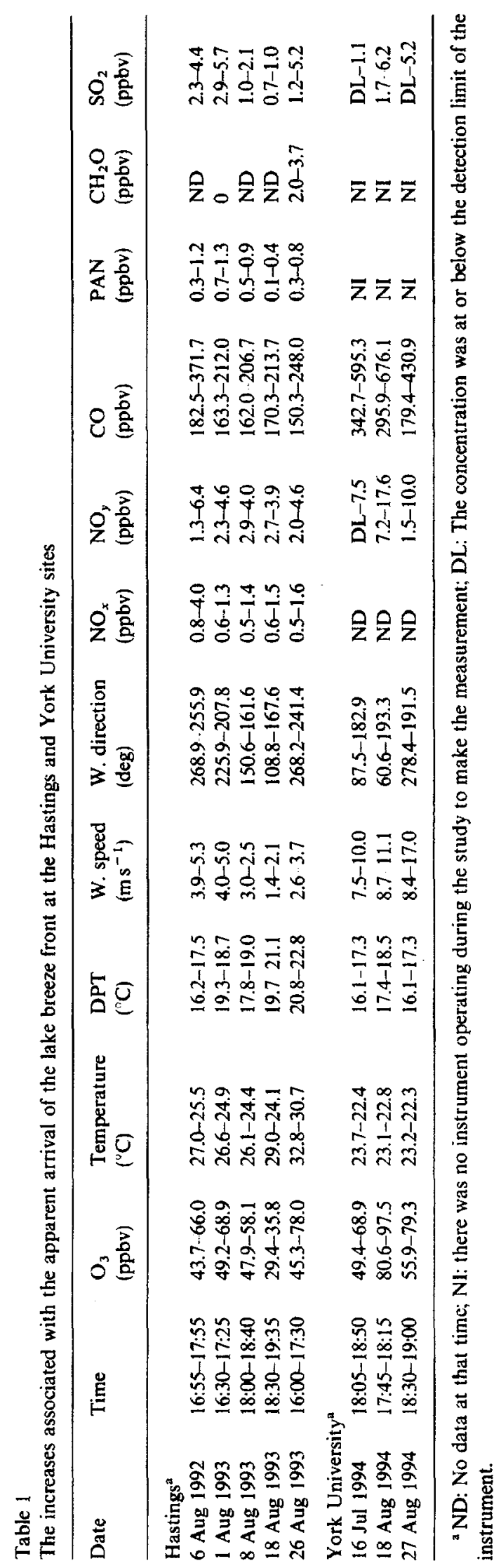


1973, 1976; Dye et al., 1995; Sillman et al., 1993; Kitada and Kitagawa, 1990; Giovanelli et al., 1993; Melas et al., 1995; Lu and Turco, 1994). During the 1992 SONTOS field study a rapid increase in the concentration of ozone and a number of other pollutants was occasionally observed in the late afternoon at the Hastings site (Reid et al., 1996). Recently, Sills and Moroz (1996) have examined the lake breeze circulation in this area and its possible involvement in the transportation of polluted air mass inland. It is now believed that the observed $\mathrm{O}_{3}$ increase resulted from the transport of polluted air by the lake breeze circulation.

The interest in the lake breeze circulation in the WQC arises because the typical meteorological conditions that lead to incidences of elevated ozone concentrations are the light winds, clear skies and high temperatures that most commonly occur on the back side of a high pressure system (CCME, 1991). These conditions are also conducive to the formation of well-developed lake breezes that have the potential to penetrate well inland. Thus, elevated ozone concentrations and the influence of the lake breeze, in the WQC, appear to be highly correlated.

\subsection{Evidence for the impact of the lake breeze}

There are many instances of the rapid increase in ozone concentration at the SONTOS sites first identified in Reid et al. (1996) that are now attributed to lake breeze

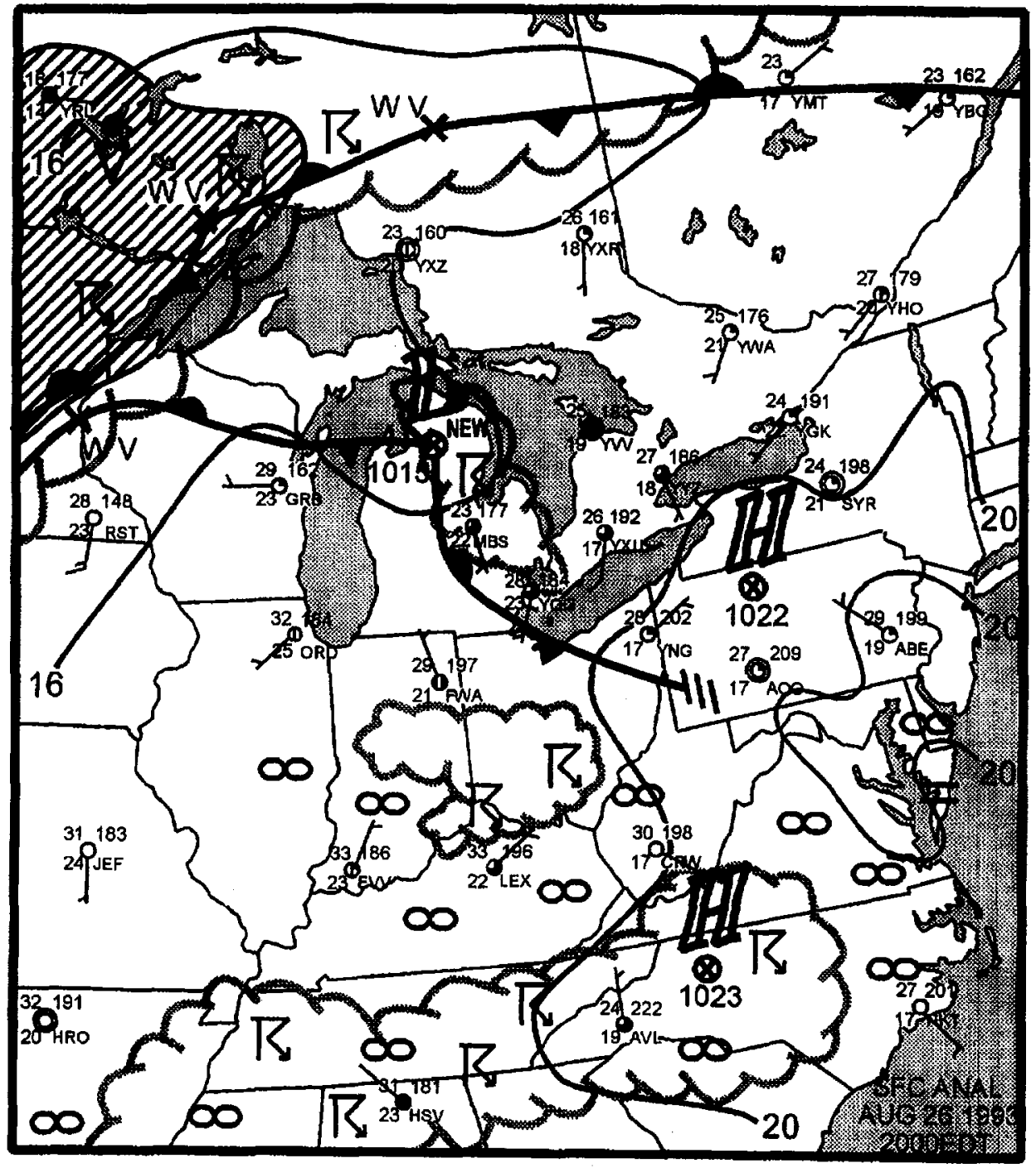

Fig. 1. Synoptic surface analysis at 2000 EDT, 26 August 1993. Hatched area in the top left indicates widespread rain shower activity; the grey scalloped lines outline areas of significant cloud cover; the thick black lines indicate fronts; and the thin black lines are isobars with a $4 \mathrm{mb}$ contour interval. 
circulation. Of these, there are a number which occurred during the SONTOS intensive studies and for which there are a large number of meteorological and chemical measurements. In addition to the 6 August 1992 event already described in Reid et al. (1996), there are detailed measurements during four similar rapid increases of ozone and other pollutant concentrations in the late afternoon from the 1993 study at Hastings, and three such cases at York in 1994. The observed increases for these cases are shown in Table 1. For each case the time of the event and the measured parameters immediately before and after the event are listed. Of these events, the most extensive data are from 26 August 1993. This case, and an event from York, will be discussed in detail.

\subsection{Hastings, 26 August 1993}

The synoptic surface analysis at 2000 EDT is shown in Fig. 1 and shows a broad ridge of high pressure over southeastern Ontario. Skies along the north shore of Lake Ontario and over the Hastings site were partly cloudy and winds were light over the entire Lake Ontario region. A weak gradient flow existed from the west to south west throughout the day. There is an obvious band of clouds in visible satellite images that indicate a welldeveloped lake breeze front was present from the early afternoon to the early evening. Figure 2 summarizes the information from these images (not shown) illustrating the inland progress of this front from the shore of Lake Ontario. It shows that as the afternoon progressed the front advanced steadily inland. As would be expected, the greatest penetration was from the northern shore where the gradient flow and the onshore lake breeze flow directions are coincident (Atkins and Wakimoto, 1997). The front appears to pass Hastings between 1600 and $1800 \mathrm{~h}$, but is no longer discernable after this time.

Fig. 3a and $b$ shows meteorological data from Hastings that confirm the passage of a lake breeze front near $1700 \mathrm{~h}$. As the front passed, the wind speed increased from 2 to $4 \mathrm{~m} \mathrm{~s}^{-1}$ and the wind direction backed from westerly to southwesterly and became much more steady. A temperature decrease from 33 to $31^{\circ} \mathrm{C}$ and an increase in the dew point temperature from 21 to $23^{\circ} \mathrm{C}$ signified the arrival of the cooler, more humid lake air. Further, the eppley radiometer showed a momentary decrease in solar radiation consistent with a band of clouds as the lake breeze front passed over the site.

Chemical measurements show a marked change in air composition concurrent with this frontal passage. The time series for a number of chemical parameters measured at Hastings are presented in Fig. $3 \mathrm{c}$ and $\mathrm{d}$. The ozone concentration had risen steadily during the day, from $20 \mathrm{ppbv}$ overnight to $42 \mathrm{ppbv}$ at $1700 \mathrm{~h}$. (The increase in ozone just prior to $1500 \mathrm{~h}$ will be discussed

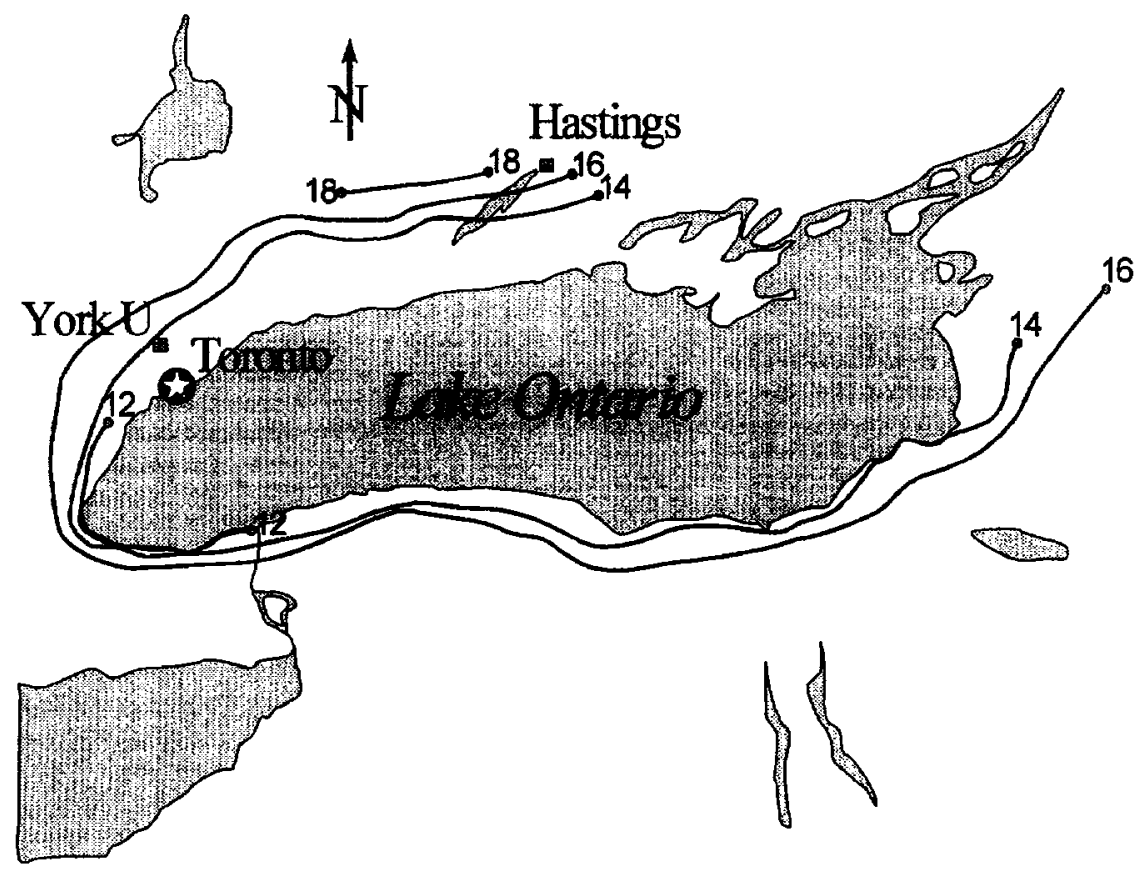

Fig. 2. Diagram illustrating the inland penetration of the Lake Ontario lake breeze with time on 26 August 1993 . The contours represent segments of the lake breeze front apparent on visible satellite imagery. The front may actually be continuous around the entire perimeter of the lake. Times are given in EDT. Note that the front passes Hastings between 1600 EDT and 1800 EDT. 


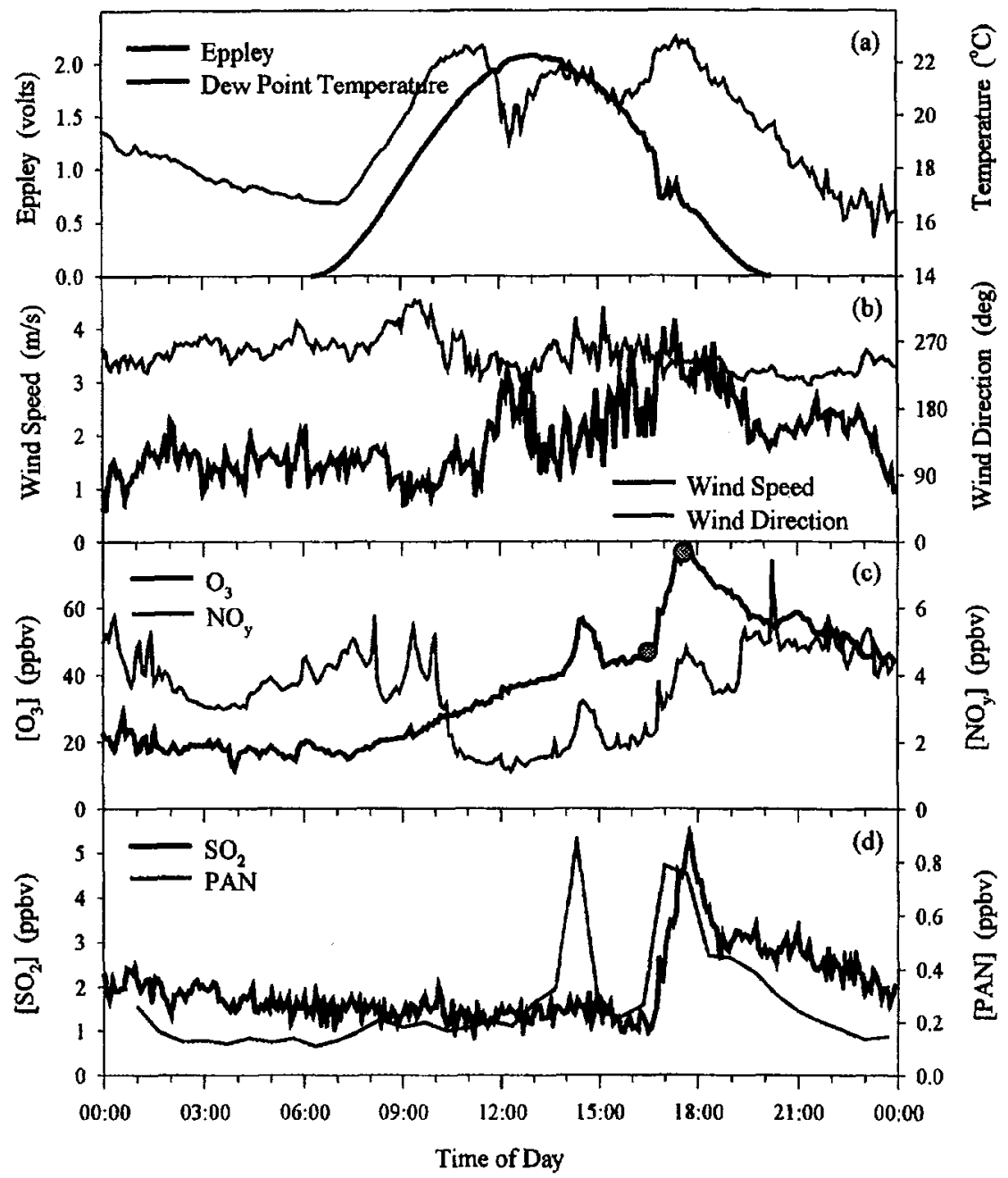

Fig. 3. (a) Dew point temperature $\left({ }^{\circ} \mathrm{C}\right.$ ) and UV solar radiation from an eppley radiometer (volts); (b) wind speed (m $\mathrm{s}^{-1}$ ) and wind

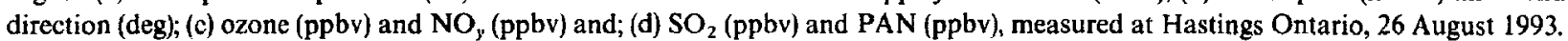

below.) However, much higher concentrations were being measured during this time upwind of the site. The network data from the ground-level station in Toronto showed an average surface concentration of $\sim 60 \mathrm{ppbv}$ from 1200 to $2100 \mathrm{~h}$ and those from the $440 \mathrm{~m}$ level of the $\mathrm{CN}$ tower (located on the lake shore at Toronto) showed a constant concentration of $80 \mathrm{ppbv}$ over the same time period. With the arrival of air from the lake, the ozone concentration at Hastings rose from 42 to $80 \mathrm{ppbv}$ in 20 min. Increases in $\mathrm{NO}_{x}, \mathrm{NO}_{y}, \mathrm{CO}, \mathrm{SO}_{2}, \mathrm{PAN}$, and $\mathrm{CH}_{2} \mathrm{O}$ were observed concurrent with this ozone increase. $\mathrm{Hy}$ drocarbon canister samples are available from before and immediately after the passage of the front as indicated by the dots on the ozone measurements in Fig. 3. These data, shown in Fig. 4, show that, with the exception of the biogenic hydrocarbon isoprene, the concentrations of the hydrocarbons also increased upon passage of the front. The increases in $\mathrm{NO}_{y}, \mathrm{CO}$ and hydrocarbons indicate that the incoming air is more polluted than the existing rural air mass. However this pollution is not due to a local source. The increases in the secondary pollutants, ozone, PAN and $\mathrm{CH}_{2} \mathrm{O}$ show that the precursors have had sufficient time for significant photochemical processing to take place. $\mathrm{PAN}$ and $\mathrm{CH}_{2} \mathrm{O}$ are particularly useful indicators as they are, in general, well correlated with ozone production (Roberts et al., 1995) but are relatively short-lived. Therefore, they are good indicators of recent or local-scale photochemical activity. In this case they suggest that the observed increase in ozone is likely a result of relatively recent $(<1 \mathrm{~d})$ photochemical production. Further support for the incoming air mass being processed comes from using the $\mathrm{NO}_{x} / \mathrm{NO}_{y}$ ratio as a measure of photochemical age. Prior to the arrival of the lake-air, this ratio was around 0.28 


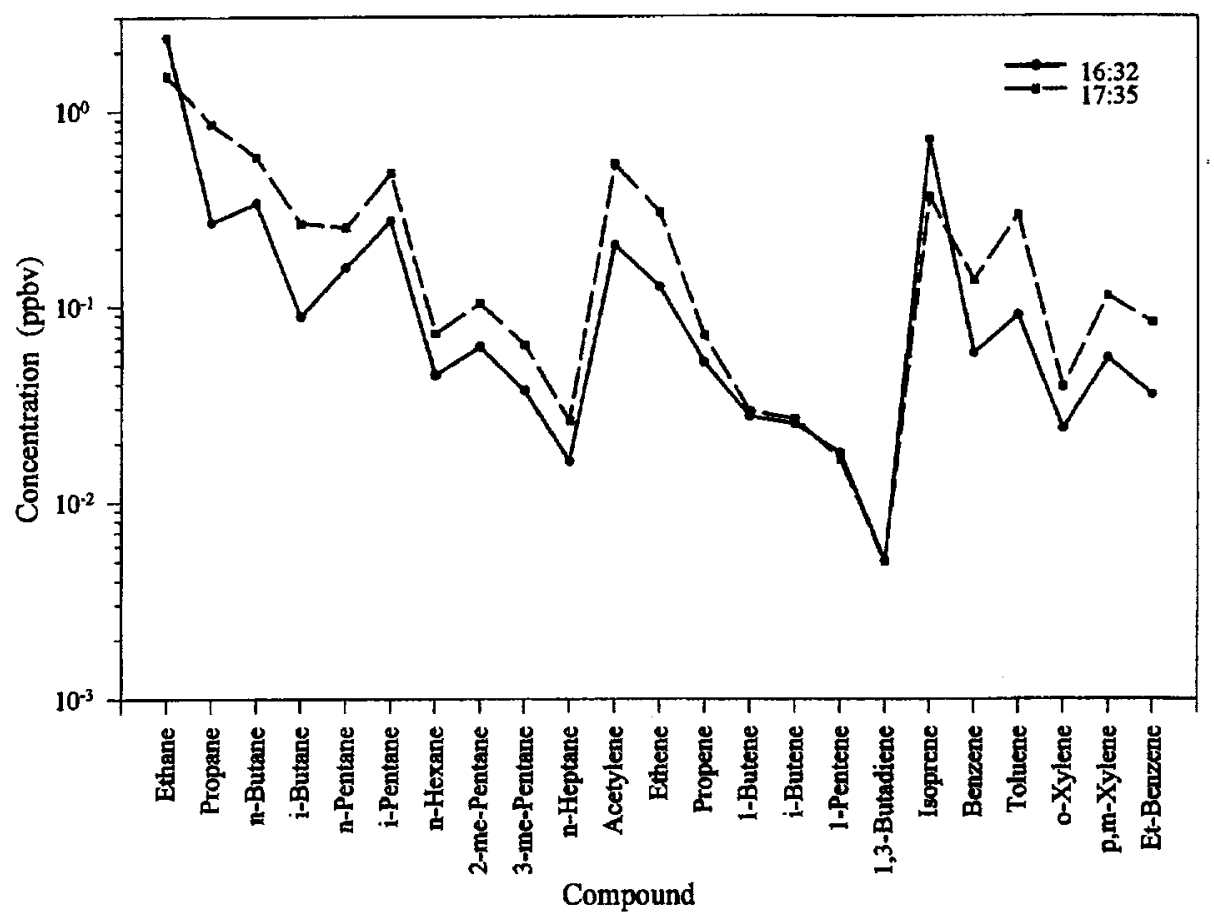

Fig. 4. Hydrocarbon concentrations (ppbv) measured at Hastings Ontario before and after lake breeze event on 26 August 1993 . The times of these measurements are indicated by the large dots in Fig. 3(c).

indicating that the rural air being sampled had undergone significant processing. Behind the front the ratio was identical, indicating that the pollutants in the air behind the front have also had opportunity to undergo appreciable photochemical processing.

The aircraft measurements show a very inhomogeneous distribution of ozone and $\mathrm{NO}_{x}$ over the area, on this day. Fig. $5 a$ and $b$ gives the time series and location of measurements from the aircraft. From the early afternoon flight from Guelph to Peterborough (1215-1400 h), the ozone concentration upwind of Toronto was observed to be $\sim 80 \mathrm{ppbv}$ with the $\mathrm{NO}_{x}$ concentration varying from 1 to $7 \mathrm{ppbv}$. The plume of $\mathrm{NO}_{x}$ coincides with a decrease in ozone concentration, implying it is a relatively fresh emission, possibly from the Nanticoke thermal generating station on the north shore of Lake Erie. The $\mathrm{NO}_{x}$ was found to increase again offshore from Toronto, but this air mass appears to be more aged than found upwind, as it produced an increase in ozone to over $90 \mathrm{ppbv}$. As the aircraft flew at a height of $400 \mathrm{~m}$ parallel to the shore, away from Toronto, the ozone concentration dropped to as low as $70 \mathrm{ppbv}$ but abruptly increased reaching over $100 \mathrm{ppbv}$ at a location over the lake. The $\mathrm{NO}_{x}$ concentration increased on the transition into this air mass but rapidly decreased to remain only slightly elevated. On turning inland (position marked 4) the ozone and $\mathrm{NO}_{x}$ concentrations dropped to values more in keeping with the concurrent observations at Hastings, namely below 60 and $1.5 \mathrm{ppbv}$, respectively. The lack of ozone and $\mathrm{NO}_{x}$ variations with height over Hastings (position 5) show the decrease on turning inland was not due to the required change in aircraft altitude. These concentrations persisted for the rest of the flight over the land. On the return flight $\left(1515-1730\right.$ h) shown in Fig. 5b, similar ozone and $\mathrm{NO}_{x}$ concentrations to those of the earlier flight were measured between Peterborough and Hastings. As the aircraft flew towards the lake it encountered a high concentration air mass with over 90 ppbv of ozone and 2 ppbv of $\mathrm{NO}_{x}$. The flight track for this flight was almost identical to that on the earlier flight so this air mass appears to be the same as was encountered some $2 \mathrm{~h}$ earlier over Lake Ontario. The aircraft passed through this air mass and as it headed back over the lake and towards Toronto the ozone concentration remained at $\sim 80-90 \mathrm{ppbv}$ and the $\mathrm{NO}_{x}$ concentrations increased steadily. Higher ozone concentrations of over $90 \mathrm{ppbv}$ were encountered at $400 \mathrm{~m}$ altitude close to Toronto, consistent with the $\mathrm{CN}$ tower measurement of 80-90 ppbv at that time. Concentrations dropped as the aircraft moved upwind of Toronto but encountered higher concentrations of both ozone and $\mathrm{NO}_{x}$ as it returned to Guelph. Vertical profile measurements were made from 400 to $800 \mathrm{~m}$ over Hastings on both flights, at 1340 and $1535 \mathrm{~h}$, respectively. 
These profiles show little variation in ozone or $\mathrm{NO}_{x}$ concentrations over this altitude range and values consistent with those being measured at the surface. There is no evidence for vertically stratified pollutant layers, at least to $800 \mathrm{~m}$, and thus there appears to be no support for the increase in surface concentrations arising solely from downward mixing. Thus, the aircraft measurements show $\mathrm{NO}_{x}$ and ozone concentrations consistent with those measured at Hastings prior to the arrival of the lake breeze, and they show an air mass moving inland from the lake that has comparable concentrations to those seen behind the front.

The surface and aircraft observations all point to the incoming air mass being highly polluted, having undergone significant photochemical processing, having orig- inated over Lake Ontario and having been transported to the site by the lake-breeze circulation.

While it is clear that the lake breeze is bringing polluted air in from Lake Ontario, there are two other issues which need to be addressed. What is the origin of the polluted air over the lake and why are the increases in concentration of such short duration?

The source of the high concentrations over Lake Ontario must be the regions surrounding it. Longer range transport is unlikely given the degree of chemical processing in the air masses impacting Hastings. With the lake breeze circulation taking air from above Lake Ontario for most of the day, any accumulation of pollutants must take place prior to its development. Prior to sunrise, a weak land breeze could advect material from the
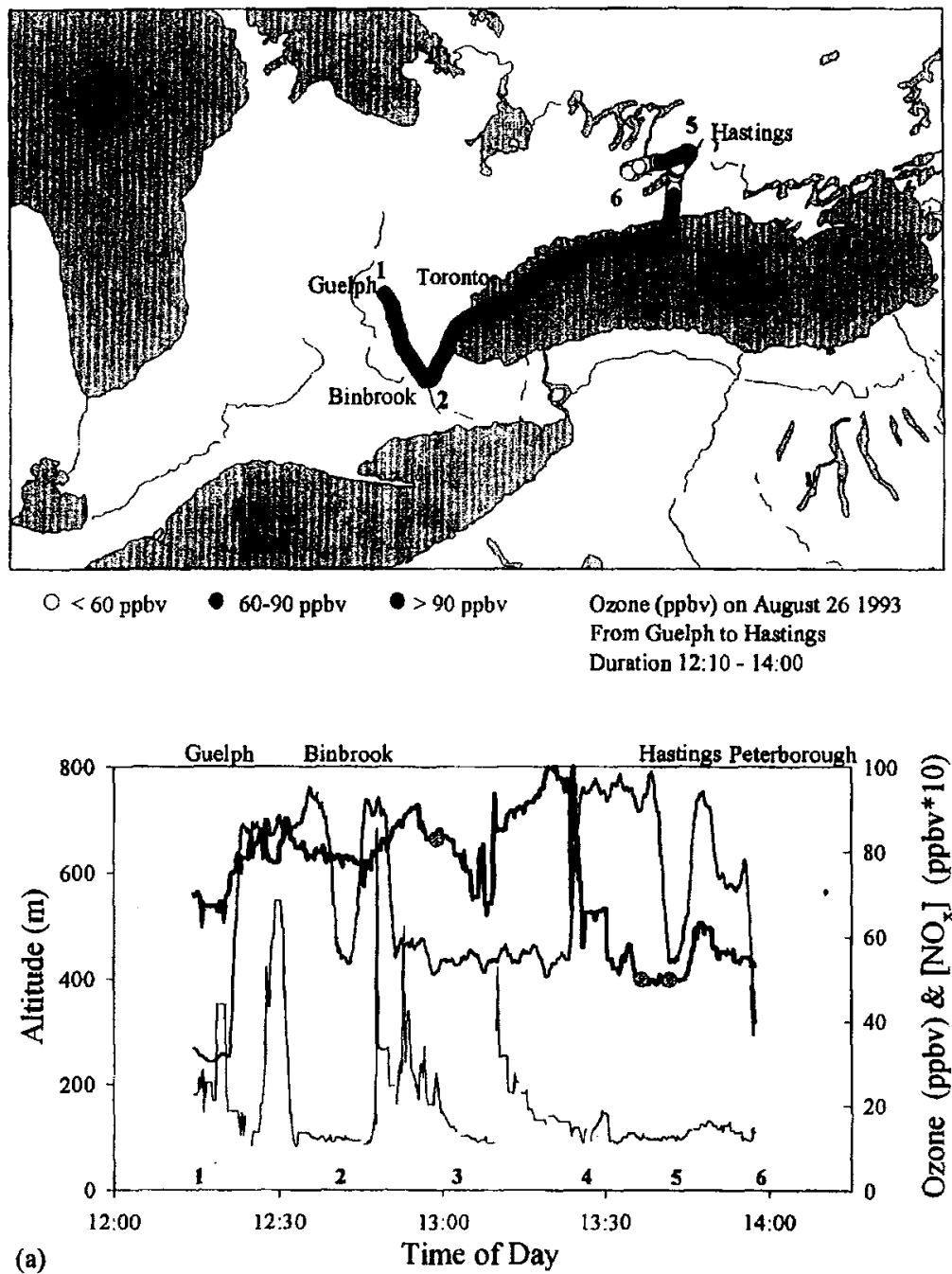

Fig. 5a. Upper panel: Flight track taken by the aircraft from Guelph to Hastings on 26 August 1993. The ozone concentration is represented by the density of the dots. Lower panel: ozone concentration (ppbv) (thickest line), $\mathrm{NO}_{x}$ concentration (ppbv) (thinnest line) and altitude $(\mathrm{m})$ (medium thickness line) as a function of time and location for the same flight. The numbers along the time axis correspond to the positions in the upper panel. 

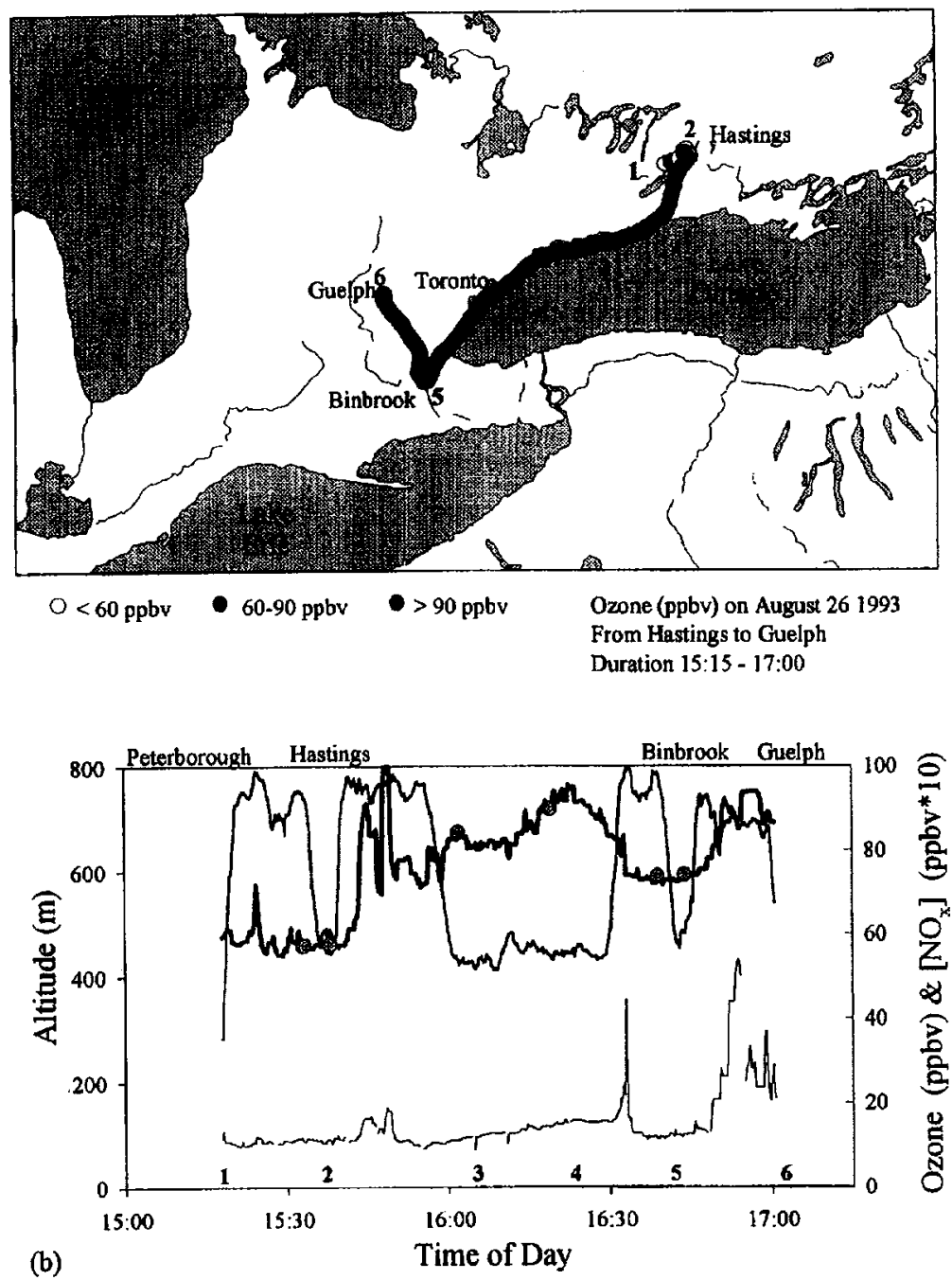

Fig. 5b. Upper panel: Flight track taken by the aircraft from Hastings to Guelph on 26 August, 1993. The ozone concentration is represented by the density of the dots. Lower panel: ozone concentration (ppbv) (thickest line), NO $x$ concentration (ppbv) (thinnest line) and altitude $(\mathrm{m})$ (medium thickness line) as a function of time and location for the same flight. The numbers along the time axis correspond to the positions in the upper panel.

source regions on land over the lake. After the land breeze decays, flow into the near surface layers above the lake would cease and the air mass would likely remain over the lake or move with the gradient flow until moved inland by the lake breeze circulation. Lyons and Cole (1976) postulated this mechanism for the Chicago area and Lake Michigan although the observed impacts in this case were only up to $13 \mathrm{~km}$ inland. The air over the lake would undergo less vertical mixing than would take place over the land. Thus the precursors over the lake would not be dispersed as effectively as later emissions over land, and their concentrations could remain relatively high. Satellite photographs show little cloud over Lake Ontario on days when there is a lake breeze and so this polluted airmass would undergo significant photo- chemical processing. In addition, a shallow conduction inversion would form over the lake after sunrise. This would inhibit deposition to the lake surface which would also contribute to maintaining high pollutant concentrations over the lake.

The arrival of the lake breeze front appears to give rise to a short-lived maximum in trace gas concentration rather than a constant elevated level as may be expected from the incursion of the different air mass. In the August 26 case the concentrations decrease for almost $2 \mathrm{~h}$, until about $1830 \mathrm{~h}$. At that time, the decrease in the ozone concentration and the increases in humidity and the concentrations of the primary pollutants indicate the formation of a nocturnal boundary layer (Hastie et al., 1993). The rapid decrease behind the lake-breeze front 
could result from the vertical mixing generated by the front itself. This may result in cleaner air, from above the inflow layer, being entrained downwards behind the front which would dilute the airmass. This process would result in a decrease in the maximum concentration of all pollutant species as the lake breeze front moves inland. There is a suggestion that this may be the case in the aircraft data. The maximum ozone concentration is lower when the polluted air mass is encountered over the land than when it was over the lake, even though more ozone would have been produced in the $2 \mathrm{~h}$ between measurements.

The surface data from Hastings also show an increase in the concentrations of most of the chemical species at around $1400 \mathrm{~h}$. The data indicate a similar signature to the later event but while it is clearly due to an intrusion of more polluted air, it differs from all other cases we have studied in that it occurs much earlier in the day and is not associated with an increase in humidity nor a decrease in temperature or solar radiation. Also the satellite images show the Lake Ontario lake breeze front to be only about half way between the lake and the site. The chemical data are also inconsistent, as there is no increase in $\mathrm{SO}_{2}$ or $\mathrm{CO}$ associated with the increases in $\mathrm{NO}_{x}, \mathrm{NO}_{y}, \mathrm{PAN}$ and
$\mathrm{CH}_{2} \mathrm{O}$. The only conclusion we can draw is that the atmosphere in this area is still far from homogeneous even though the site is some $150 \mathrm{~km}$ from the major source region.

\subsection{York University $16 \mathrm{July} 1994$}

While the chemical data at York are not as comprehensive as the data set obtained at Hastings and there are no supporting aircraft data, we have identified three cases where the lake breeze appears to impact the York site, bringing with it elevated concentrations of oxidants and precursors. These data are summarized in Table 1. The most notable day was 16 July 1994.

Visible satellite images, for $16 \mathrm{July}$, indicate that a welldeveloped lake breeze front was present on this day and the progress of this front is shown in Fig. 6. The gradient flow was much weaker on this day, than in the previous case, and was from the north to north east. Thus, the front penetrated further to the south and southwest of the Lake, than to the north. It appears to pass over the York site between 1700 and $1900 \mathrm{~h}$.

Fig. 7 shows the meteorological and chemical data measured at York on this day and it appears from these

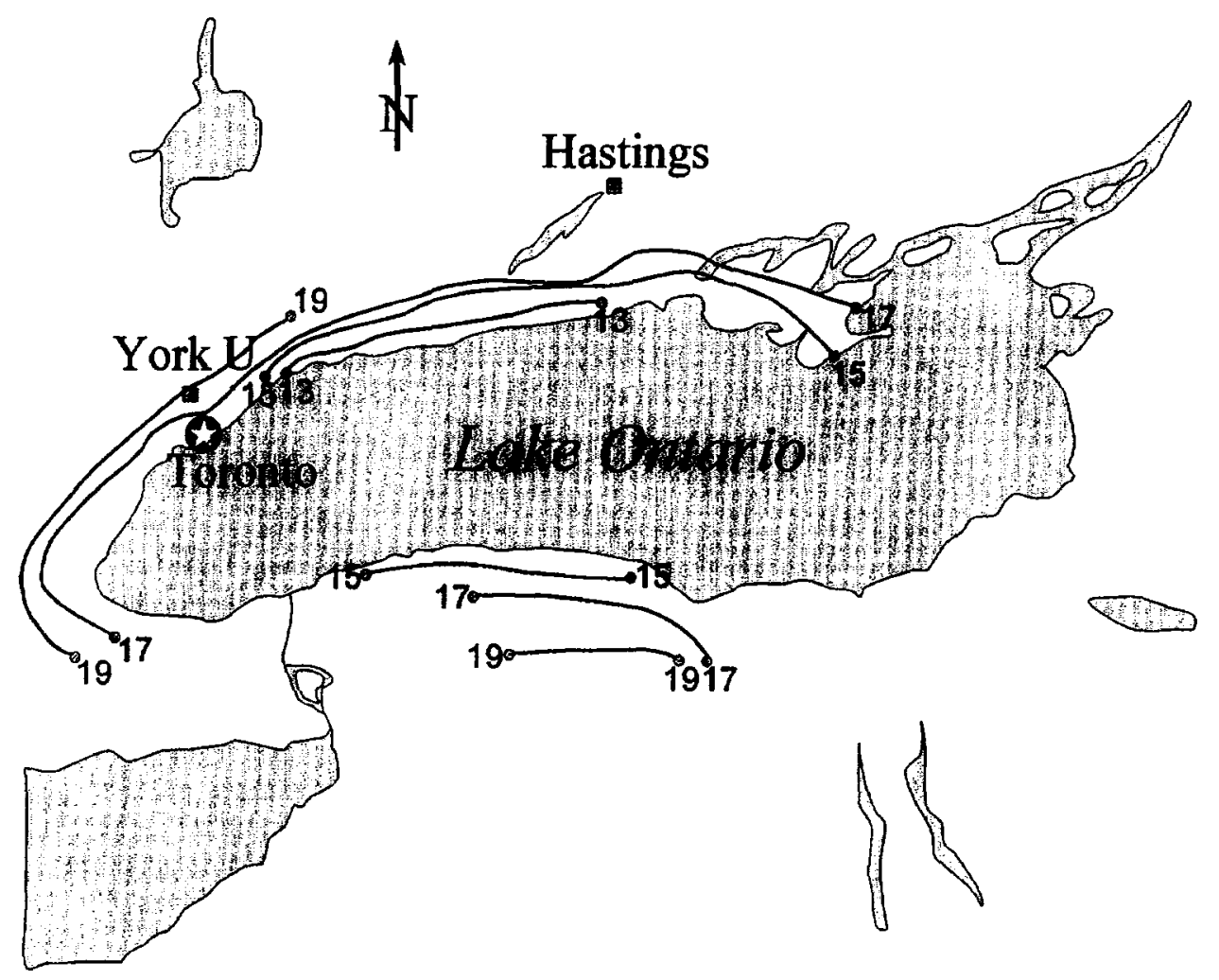

Fig. 6. Diagram illustrating the inland penetration of the Lake Ontario lake breeze with time on 16 July 1994. The contours represent segments of the lake breeze front apparent on visible satellite imagery. The front may actually be continuous around the entire perimeter of the lake. Times are given in EDT. Note that the front passes York University between 1700 EDT and 1900 EDT. 


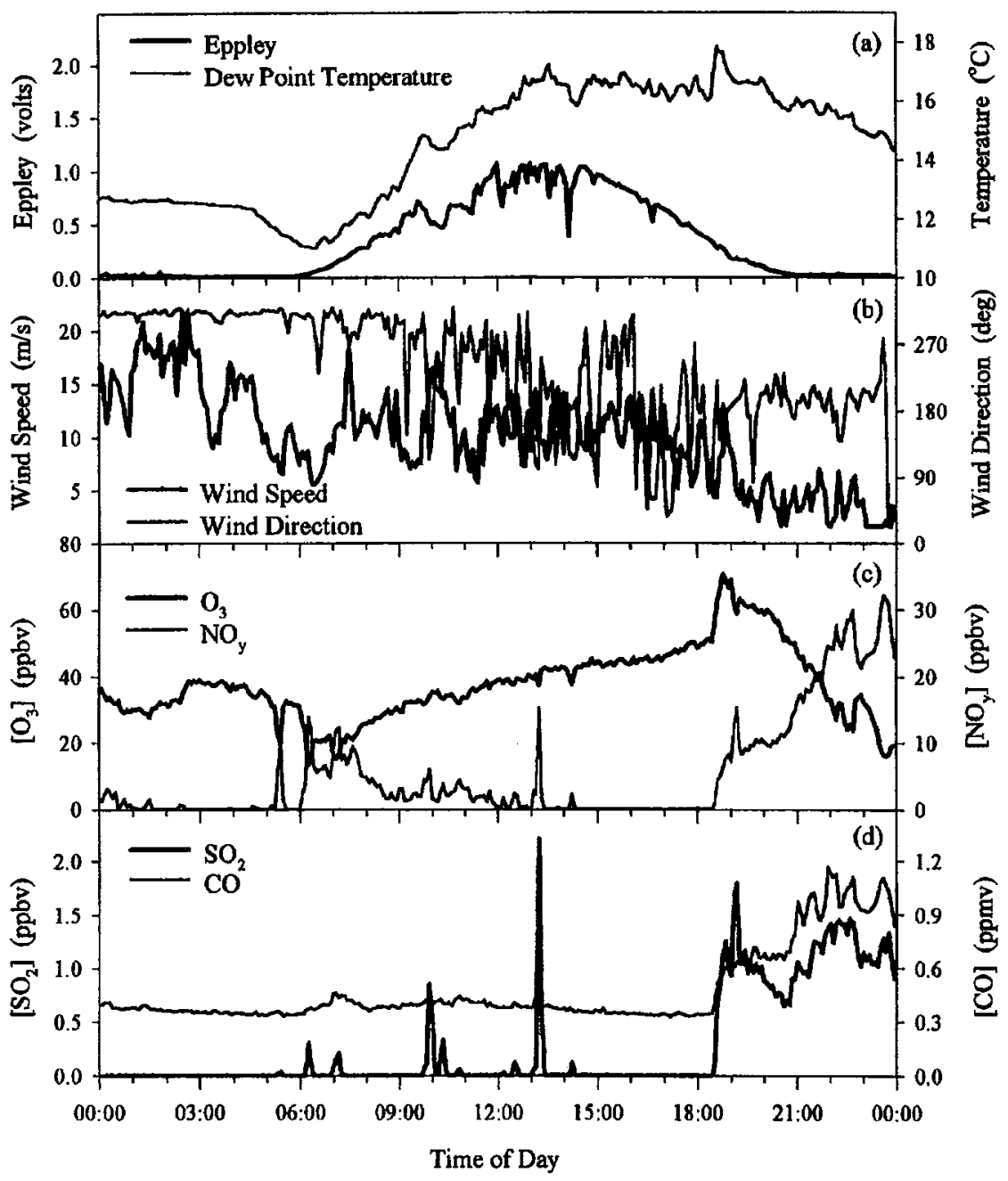

Fig. 7. (a) Dew point temperature ("C) and U. V. solar radiation from an eppley radiometer (V); (b) Wind speed (ms ${ }^{-1}$ ) and wind direction (deg); (c) ozone (ppbv) and $\mathrm{NO}_{y}$ (ppbv) and; (d) $\mathrm{SO}_{2}$ (ppbv) and $\mathrm{CO}$ (ppbv), measured at York University, 16 July 1994.

data that a lake breeze front passes the site at around $1830 \mathrm{~h}$, consistent with the satellite images. The arrival of the front is characterized by an increase in dewpoint temperature and a shift in wind direction to bring air from Lake Ontario. As at Hastings, the incoming air mass has elevated concentrations of both the primary pollutants $\mathrm{SO}_{2}, \mathrm{NO}_{y}$ and $\mathrm{CO}$ and the secondary pollutant ozone. The observed increases in precursor concentrations are especially surprising as the site is located in a suburban area within the boundaries of Metropolitan Toronto. This further supports the contention that the pollutants are constrained over the lake, and that the cool, dense air flows to the site with little impact of dilution and mixing. The presence of high ozone concentrations again shows that the air mass behind the front has undergone significant processing and the high concentrations do not result from local emissions.
From the limited measurements available, the characteristics of the ozone enriched air reaching the York site are similar to those reaching the Hastings site behind the lake-breeze front, and the mechanism for its transport appears to be the same.

\section{Conclusions}

The data presented here show that there are cases where the air masses over Lake Ontario contain ozone, ozone precursors and other oxidation products at concentrations higher than over adjacent land areas. In these cases, the Lake Ontario lake breeze has been shown to advect this material inland giving a measurable impact on air quality. The origin of these polluted air masses is postulated to be emissions from the source 
areas that are entrained over the lake by the nighttime land breeze.

An especially significant feature of this lake breeze impact is that, at a particular location, it may cause the ozone concentration to rapidly increase by tens of ppbv late in the day. This may only be a short lived effect as the surface ozone concentration generally falls shortly afterwards as the nocturnal inversion forms. To use this short-lived, elevated value as representative of the entire day's air quality is misleading. As an example, for the 26 August 1993 event at Hastings, the peak concentration was $80 \mathrm{ppbv}$ and the maximum hourly average was $74 \mathrm{ppbv}$. The $8 \mathrm{~h}$ average concentration ending at the same time was $45 \mathrm{ppbv}$, and the median value for the $8 \mathrm{~h}$ was 42.2 ppbv. Normally, the ozone maximum is in the early afternoon (Hastie et al.. 1996) when the solar radiation, temperature, and photosynthetic activity are still high and the impact of ozone also expected to be high. The late afternoon maxima induced by the lake breeze occur at a time when photosynthetic rates are lower and the ozone impact is also expected to be lower. If the purpose of air quality standards is to protect vegetation, the use of $1 \mathrm{~h}$ standards will over estimate the importance of these excursions late in the day.

This work also points to the importance of the placement of monitors to determine the ozone exposure, particularly in rural areas. The extremely spatially inhomogeneous nature of the ozone distribution, and the intermittent nature of the lake breeze impact, means that a small number of monitors may misrepresent ozone exposures. This is especially important in southern Ontario where agricultural land runs from Lakes Erie and Ontario in the south, to the edge of the Canadian shield less than $100 \mathrm{~km}$ further north. The impact of the lake breeze has been shown to penetrate at least half that distance so that a very large fraction of this area could potentially have misrepresented exposures.

The modelling of the elevated concentrations over the Great Lakes and the impact of the lake breeze in transporting this material inland is critical to the prediction of the ozone concentration impacting a particular location. Calculations by Sillman et al. (1993) and Plummer (1995) have shown that, with limited mixing over the lake and little deposition, substantially elevated precursor and ozone concentrations can be generated. It now remains for such simulations to be included into a mesoscale meteorological model of sufficiently high resolution to accurately represent the lake-land circulation.

\section{Acknowledgements}

We gratefully acknowledge the financial support of the Ontario Ministry of the Environment and Energy, Ontario Hydro and CIRAC. This work is part of the SONTOS project and this is paper \# 97/ of CIRAC. We acknowledge the inputs of M.C. Arias, S. Campagnolo, W. Polesal, and S. Laszlo to the collection of the data. Thanks to G. DeBrou and D. Yap of MOEE for the network ozone data, and P. King of AES for the GOES-7 satellite images.

\section{References}

Atkins, N.T., Wakimoto, R.M., 1997. Influence of the SynopticScale Flow on Sea Breezes Observed during CaPE. Monthly Weather Reviews 125, 2112-2130.

CCME, 1991. Canadian Council of Ministers of the Environment. Federal/Provincial LRTAP Steering Committee. Management Plan for Nitrogen Oxides $\left(\mathrm{NO}_{x}\right.$ ) and Volatile Organic Compounds (VOCs).

Comer, N.T., McKendry, I., 1993. Observations and Numerical Modelling of Lake Ontario Breezes. Atmos-Ocean 31, 481-499.

Drummond, J.W., Castledine, C., Green, J., Denno, R., Mackay, G. I., Schiff, H.I., 1989. New technologies for use in acid deposition networks. In: Zielinski, Jr. E.W.L. (Ed.), Monitoring Methods for Toxics in the Atmosphere, ASTM STP 1052. American Society for Testing and Materials, Philadelphia, PA.

Dye, T.S., Roberts, P.T., Korc, M.E., 1995. Observations of transport processes for ozone precursors during the 1991 Lake Michigan Ozone Study. American Meteorological Society $34,1877-1889$.

Fortezza, F., Strocchi, V., Giovanelli, G., Bonasoni, P., Georgiadis, T., 1993. Transport of photochemical oxidants along the northwestern Adriatic coast. Atmospheric Environment 27A, 2393-2402.

Hastie, D.R., Shepson, P.B., Sharma, S., Schiff, H.I., 1993. The influence of the Nocturnal boundary layer on the concentration of secondary trace species at Dorset. Ontario. Atmospheric Environment 27A, 533-541.

Hastie, D.R., Shepson, P.B., Reid, N., Roussel, P.B., Melo, O.T., 1996. Summertime $\mathrm{NO}_{x}, \mathrm{No}_{y}$, and ozone at a site in Rural Ontario. Atmospheric Environment 30, 2157-2165.

Jobson, B.T., Wu, Z., Niki, H., Barrie, L.A., 1994. Seasonal trends of isoprene, $C_{2}-C_{5}$ alkanes and acetylene at a remote boreal site in Canada. Journal of Geophysics Research 99, 1589-1599.

Kitada, T., Kitagawa, E., 1990. Numerical analysis of the role of sea breeze fronts on air quality in coastal and inland polluted areas. Atmospheric Environment 24A, 1545-1559.

Lu, R., Turco, R.P., 1994. Air pollutant transport in a coastal environment. Part I: two-dimensional simulations of seabreeze and mountain effects. American Meteorological Society $15,2285-2308$.

Lyons, W.A., 1972. The Climatology and Prediction of the Chicago Lake-breeze. Journal of Applied Meteorology 11, 1259-1270.

Lyons. W.A., Cole, H.S., 1973. Fumigation and plume trapping on the shores of Lake Michigan during stable onshore flow. Journal of Applied Meteorology 12, 494-510.

Lyons, W.A., Cole, H.S., 1976. Photochemical oxidant transport: mesoscale lake breeze and synoptic-scale aspects. Journal of Applied Meteorology 15, 733-743. 
Melas, D., Ziomas, J.C., Zerefos, C.S., 1995. Boundary layer dynamics in an urban coastal environment under sea breeze conditions. Atmospheric Environment 29, 3605-3617.

Plummer, D.A., 1995. Modelling of ozone formation at a rural site in Southern Ontario. M.Sc. Thesis, York University.

Reid, N.W., Niki, H., Hastie, D.R., Shepson, P.B., Roussel, P.B., Melo, O.T., Mackay, G.I., Drummond, J., Schiff, H.l., Poissant, L., Moroz, W., 1996. The Southern Ontario Oxidant Study (SONTOS): Overview and Case Studies for 1992. Atmospheric Environment 30, 2125 2132.

Roberts, J.M. et al., 1995. Relationships between PAN and Ozone at sites in eastern North America. Journal of Geophysical Research 100, 22,821-22830.

Roussel, P.B., Lin, X., Camacho, F., Laszlo, S., Taylor, R., Melo. O.T., Shepson, P.B., Hastie, D.R., Niki, H., 1996. Observa- tion of $\mathrm{O}_{3}$ and precursors levels at two sites around toronto-Ontario During SONTOS 92. Atmospheric Environment 30, 2145-2156.

Sillman, S., Samson, P.J., Masters, J.M., 1993. Ozone production in urban plumes tansported over water: photochemical model and case studies in the Northeastern and Midwestern United States. Journal of Geophysical Research 98, 12,687-12,699.

Sills, D.M.L., Moroz, Wm.J., 1996. Lake breeze circulations resulting in elevated ozone concentrations at Hastings, Ontario. Proceedings of the 89th Annual Air and Waste Management Association Conference, Paper 96TP23B.05.

Simpson, J.E., 1994. Sea Breeze and Local Wind. Cambridge University Press, Cambridge. 